\title{
Perlindungan Hukum terhadap Pemuda Dari Kejahatan Terorisme Di Wilayah Hukum Provinsi Jambi
}

\author{
Ferdricka Nggeboe $^{1 *}$, Reza Iswanto ${ }^{2}$, Sriayu Indah Puspita ${ }^{3}$ \\ ${ }_{1,2,3}$ Fakultas Hukum Universitas Batanghari \\ Jalan Slamet Riyadi Broni Kota Jambi Telp: (0741) 65351 \\ *Correspondence email: ferdricka.nggeboe@yahoo.com; rezaiswanto17@gmail.com; izzy_euys@yahoo.com
}

\begin{abstract}
Abstrak. Pada penelitian perlindungan hukum terhadap pemuda dari kejahatan terorisme di wilayah hukum Provinsi Jambi bertujuan untuk mengetahui bentuk perlindungan dari pemerintah dan penegak hukum Provinsi Jambi. Obyek peneltiannya adalah perlindungan hukum terhadap pemuda. Permasalahan dalam hal ini yaitu bagaimana perlindungan hukum terhadap pemuda dari kejahatan terorisme di wilayah hukum Provinsi Jambi. Metode penelitian yaitu normatif sehingga penelitian ini lebih bersifat deskriptif kualitatif dan bersumber dari kepustakaan. Pendekatannya adalah pendekatan kasus dan teknik pengumpulan datanya adalah studi dokumen dan analisis datanya dilakukan secara kualitatif. Hasil penelitiannya adalah perlindungan hukum terhadap pemuda dari kejahatan terorisme di wilayah hukum Provinsi Jambi dilakukan dengan cara preventif yaitu pemerintah mengeluarkan aturan hukum terkait dengan kejahatan terorisme yaitu Undang-Undang Nomor 5 Tahun 2018 untuk melindungi pemuda yang menjadi korban kejahatan terorisme, kemudian aparat penegak hukum beserta Forum Komunikasi Penanggulangan Terorisme melakukan sosialisasi/ penyuluhan terkait kejahatan terorisme, sedangkan bentuk represif yaitu pemerintah Provinsi Jambi dan aparat penegak hukum menjerat pelaku kejahatan terorisme dengan menjatuhkan sanksi pidana yang telah diatur dalam Undang-Undang Nomor 5 Tahun 2018 Tentang Perubahan Atas Undang-Undang Nomor 15 Tahun 2003 Tentang Penetapan Peraturan Pemerintah Pengganti Undang-Undang Nomor 1 Tahun 2002 Tentang Pemberantasan Tindak Pidana Terorisme Menjadi Undang-Undang.
\end{abstract}

Kata Kunci: Perlindungan Hukum; Pemuda; Kejahatan Terorisme

Abstract. Research on legal protection against youth from terrorism crimes in the jurisdiction of Jambi Province aims to determine the form of protection from the government and law enforcement in Jambi Province. The object of his research is legal protection for youth. The problem in this case is how the legal protection of youth from terrorism crimes in the jurisdiction of Jambi Province. The research method is normative so that this research is more descriptive qualitative in nature and sourced from literature. The approach is a case approach and the data collection technique is document study and data analysis is done qualitatively. The result of his research is that legal protection for youth from terrorism crimes in the jurisdiction of Jambi Province is carried out by means of preventive means, namely the government issues legal rules related to terrorism crimes, namely Law Number 5 of 2018 to protect youth who are victims of terrorism crimes, then law enforcement officers and The Counter-Terrorism Communication Forum conducts outreach / counseling related to terrorism crimes, while the repressive form is the Jambi Provincial government and law enforcement officials to ensnare perpetrators of terrorism crimes by imposing criminal sanctions as regulated in Law Number 5 of 2018 concerning Amendments to Law Number 152003 concerning the Stipulation of Government Regulation in Lieu of Law Number 1 of 2002 Concerning the Eradication of Criminal Acts of Terrorism into Law.

Keywords: Legal Protection; Youth; Terrorism Crimes

\section{PENDAHULUAN}

Sebelum pelaku teroris tersebut melakukan aksinya yaitu dengan melakukan bunuh diri di tengah-tengah masyarakat, pelaku teroris tersebut terlebih dahulu melakukan teror terhadap korbannya. Korban dari kejahatan terorisme ini adalah masyarakat termasuk juga masyarakat Provinsi Jambi. Pelaku teroris tersebut sengaja melakukan teror guna untuk menakut-nakuti korbannya yaitu masyarakat Provinsi Jambi. Terkait dengan terjadinya teror tersebut juga telah dikemukakan dalam konvensi PBB tahun 1937, dimana dalam konvensi tersebut menjelaskan pada intinya yaitu terorisme merupakan bentuk tindak pidana (kejahatan) dan ditujukan langsung ke suatu Negara, guna untuk meneror orang tertentu maupun masyarakat. ${ }^{1}$ Oleh karena itu, sudah jelas bahwa yang menjadi korban teror dalam kejahatan terorisme ini adalah orang-orang atau kelompok seperti masyarakat Provinsi Jambi. Tujuan dilakukannya teror oleh pelaku teroris tersebut guna untuk memberi rasa ketakutan terhadap masyarakat Provinsi Jambi sehingga masyarakat Provinsi Jambi mengikuti apa yang dikehendaki oleh pelaku teroris tersebut. Jika masyarakat Provinsi Jambi telah merasa takut dan mengikuti perintah teroris tersebut maka mempermudah pelaku teroris untuk melakukan aksinya masyarakat Provinsi Jambi sesuai dengan kemauan pelaku teroris itu sendiri.

1 Abdul Wahid Sunardi dan Muhammad Imam Sidik, Kejahatan Terorisme Perspektif Agama, HAM dan Hukum, (Bandung : Retika Aditama, 2004), hal 29. 
Aksi terorisme ini tidak hanya berupa teror saja kepada siapapun yang ditujunya, melainkan juga para pelaku tindak pidana terorisme ini dalam melancarkan aksinya, apabila ada yang memperhambat atau menelusuri jejak mereka maka mereka segera melakukan kekerasan terhadap orang yang menelusuri jejak mereka bahkan sampai membunuh orang tersebut. Hal ini terjadi pada insiden penusukan yang menimpa personel Densus 88 Bripda Saud di Kabupaten Tebo. Kejadian bermula ketika Bripda Saud bersama seorang rekannya, Bripda Dedi Yonesa sedang membuntuti terduga teroris berinisial WF. Di Jalan Lintas Tebo-Bungo KM 5 Dusun Bogo Rejo, Kelurahan Tebing Tinggi, Kecamatan Tebo Tengah, Jambi, kedua anggota menghadang sepeda motor yang ditumpangi terduga teroris. ${ }^{2}$ WF langsung menjatuhkan motor R2 yang dikendarainya dan langsung menyerang Bripda Saud dan Bripda Dedi. Ketika itu terduga teroris memiliki kesempatan untuk menikam Bripda Saud menggunakan sebuah senjata tajam jenis pisau. ${ }^{3}$ Mengingat telah masuknya kejahatan terorisme di Provinsi Jambi yang berada di Kecamatan Tebo Tengah maka sudah seharusnya aparat penegak hukum dan masyarakat Provinsi Jambi harus selalu waspada terhadap siapa saja yang belum dikenal. Hal ini dilakukan demi menciptakan kesejahteraan dan keamanan di dalam masyarakat Provinsi Jambi sehingga masyarakat Provinsi Jambi dapat hidup dengan tenang tanpa adanya teror dari pelaku teroris tersebut.

Selain itu, terkait dengan menciptakan kesejahteraan dan keamanan masyarakat Provinsi Jambi dari gangguan teroris merupakan bagian dari perlindungan hak asasi manusia (HAM) karena di dalam Undang-Undang Nomor 39 Tahun 1999 Tentang Hak Asasi Manusia juga telah diatur tentang berbagai macam hak manusia. Adapun isi dari Undang-Undang Nomor 39 Tahun 1999 Tentang Hak Asasi Manusia pada Pasal 4 yaitu hak untuk hidup, hak untuk tidak disiksa, hak kebebasan pribadi, pikiran dan hati nurani, hak beragama, hak untuk tidak diperbudak, hak untuk diakui sebagai pribadi dan persamaan di hadapan hukum dan hak untuk tidak dituntut atas dasar hukum yang berlaku surut adalah hak hak manusia yang tidak dapat dikurangi dalam keadaan keadaan apapun dan oleh siapapun. Jika dilihat di dalam Pasal 4 Undang-Undang Nomor 39 Tahun 1999 Tentang Hak Asasi Manusia tersebut maka aparat penegak hukum Provinsi Jambi harus serius dalam menangani kasus kejahatan terorisme sehingga hak-hak masyarakat Provinsi Jambi dapat dilindungi dari ancaman kejahatan terorisme.

Aparat penegak hukum Provinsi Jambi sudah seharusnya melakukan penanganan yang serius terhadap kejahatan terorisme karena kejahatan terorisme juga merupakan pelanggaran hak asasi manusia (HAM) berat. Adapun yang dimaksud dengan pelanggaran HAM adalah setiap perbuatan orang/kelompok baik disengaja/tidak disengaja/kelalaian secara melawan hukum mengurangi/menghalangi/ membatasi HAM seseorang atau kelompok yang dijamin oleh undang-undang dikhawatirkan tidak akan memperoleh penyelesaian hukum yang adil dan benar berdasarkan mekanisme hukum yang berlaku. ${ }^{4}$ Dengan demikian, dapat disimpulkan bahwa terhadap pelaku yang melakukan pelanggaran HAM tidak mendapatkan penyelesaian hukum berdasarkan mekanisme hukum yang berlaku.

Selanjutnya menurut Muhtas Majda El, pelanggaran HAM berat meliputi pembunuhan massal (genocide), pembunuhan sewenang-wenang atau pembunuhan diluar putusan pengadilan (arbitrary/extra yudicial killing), penyiksaan, penghilangan orang secara paksa, perbudakan, diskriminasi yang dilakukan secara sistematis (systematic discrimination). ${ }^{5}$ Apabila dikaitkan dengan kejahatan terorisme maka sudah jelas kejahatan terorisme merupakan pelanggaran HAM berat karena kejahatan terorisme selain merupakan perbuatan berupa teror yang meresahkan masyarakat provinsi Jambi, kejahatan terorisme juga merupakan pembunuhan massal yang sewenang-wenang terhadap orang yang tidak bersalah sehingga sudah seharusnya terhadap pelaku kejahatan terorisme ini harus dihukum dengan hukuman yang seberat-beratnya.

Untuk itu pemerintah mengeluarkan aturan hukum terkait dengan kejahatan terorisme yaitu Peraturan Pemerintah Pengganti Undang-Undang Nomor 1 Tahun 2002 Tentang Pemberantasan Tindak Pidana Terorisme. Kemudian, seiring dengan berjalannya waktu maka Peraturan Pemerintah Pengganti Undang-Undang ini diperkuat lagi sehingga digantikan dengan Undang-Undang Nomor 15 Tahun 2003 Tentang Penetapan Peraturan Pemerintah Pengganti Undang-Undang Nomor 1 Tahun 2002 Tentang Pemberantasan Tindak Pidana Terorisme, Menjadi Undang-Undang.

Namun, Undang-Undang Nomor 15 Tahun 2003 ini tidak relevan lagi sehingga digantikan dengan UndangUndang Nomor 5 Tahun 2018 Tentang Perubahan Atas Undang-Undang Nomor 15 Tahun 2003 Tentang Penetapan Peraturan Pemerintah Pengganti Undang-Undang Nomor 1 Tahun 2002 Tentang Pemberantasan Tindak Pidana Terorisme Menjadi Undang-Undang. Di dalam Pasal 6 Undang-Undang Nomor 5 Tahun 2018 ini telah diatur bahwa orang yang melakukan teror terhadap orang lain maka orang (pelaku) teror tersebut dikenakan sanksi pidana penjara paling singkat 5 (lima) tahun dan paling lama 20 (dua puluh) tahun, pidana penjara seumur hidup atau pidana mati.

${ }^{2}$ https://wartakota.tribunnews.com/2019/12/19/kronologi-anggota-densus-88-ditikam-terduga-teroris-di-jambi-sempatterjadi-pergumulan-2-lawan-1, diunggah pada tanggal 26 September 2020.

3 Ibid.

${ }^{4}$ Muhtas Majda El, Dimensi Dimensi HAM, (Jakarta : PT. Raja Grafindo Persada, 2008), hal 29.

5 Ibid, hal 27. 
Diadakannya penjatuhan sanksi pidana sebagaimana yang telah dijelaskan di atas terhadap pelaku kejahatan terorisme merupakan tujuan dari hukum pidana itu sendiri. Menurut Teguh Prasetyo, tujuan dalam penjatuhan sanksi pidana terhadap orang yang melanggar hukum pidana. ${ }^{6}$ Dengan demikian, sudah jelas bahwa apabila ada orang yang telah melanggar hukum pidana termasuk juga telah melanggar Undang-Undang Nomor 5 Tahun 2018 Tentang Perubahan Atas Undang-Undang Nomor 15 Tahun 2003 Tentang Penetapan Peraturan Pemerintah Pengganti UndangUndang Nomor 1 Tahun 2002 Tentang Pemberantasan Tindak Pidana Terorisme Menjadi Undang-Undang maka orang tersebut dapat dijatuhkan dengan sanksi pidana yang tercantum di dalam Undang-Undang Nomor 5 Tahun 2018 Tentang Perubahan Atas Undang-Undang Nomor 15 Tahun 2003 Tentang Penetapan Peraturan Pemerintah Pengganti Undang-Undang Nomor 1 Tahun 2002 Tentang Pemberantasan Tindak Pidana Terorisme Menjadi Undang-Undang.

Selain itu juga, diadakannya Undang-Undang Nomor 5 Tahun 2018 Tentang Perubahan Atas Undang-Undang Nomor 15 Tahun 2003 Tentang Penetapan Peraturan Pemerintah Pengganti Undang-Undang Nomor 1 Tahun 2002 Tentang Pemberantasan Tindak Pidana Terorisme Menjadi Undang-Undang ini karena undang-undang tersebut merupakan bagian dari perlindungan hukum.

Adapun pengertian perlindungan hukum yang dijelaskan oleh Satjipto Raharjo adalah memberikan pengayoman terhadap hak asasi manusia (HAM) yang dirugikan orang lain dan perlindungan itu diberikan kepada masyarakat agar dapat menikmati semua hak-hak yang diberikan oleh hukum. ${ }^{7}$ Untuk itu, dikeluarkannya Undang-Undang Nomor 5 Tahun 2018 Tentang Perubahan Atas Undang-Undang Nomor 15 Tahun 2003 Tentang Penetapan Peraturan Pemerintah Pengganti Undang-Undang Nomor 1 Tahun 2002 Tentang Pemberantasan Tindak Pidana Terorisme Menjadi Undang-Undang karena memberikan pengayoman terhadap masyarakat dari kejahatan terorisme sehingga masyarakat Provinsi Jambi dapat menikmati hak-haknya yang sudah diberikan oleh undang-undang tersebut yaitu terbebas dari teror yang dilakukan oleh pelaku kejahatan terorisme.

Selain kasus kejahatan terorisme yang telah diberitakan di atas, di Provinsi Jambi para pelaku terorisme dapat dikatakan masih termasuk usia pemuda. Hal ini dibuktikan dengan adanya lelaki berinisial M, 29 tahun, satu dari dua orang terduga teroris yang diamankan Densus 88 anti teror, selama mengontrak bersama istrinya di salah satu rumah di kawasan Rukun Tetangga (RT) 35, Kelurahan Kenali Besar, Kecamatan Alam Barajo, Kota Jambi, diketahui tidak pernah melapor kepada ketua RT setempat. ${ }^{8}$ Jika dilihat dari usia pelaku kejahatan terorisme yang terdapat di dalam kasus di atas yang terjadi di Kota Jambi tersebut maka pelaku kejahatan terorisme tersebut dapat dikategorikan sebagai bagai pemuda. Hal ini telah diatur dalam ketentuan umum pada Pasal 1 ayat 1 Undang-Undang Nomor 40 Tahun 2019 tentang Kepemudaan yang berbunyi yaitu pemuda adalah warga negara Indonesia yang memasuki periode penting pertumbuhan dan perkembangan yang berusia 16 (enam belas) sampai 30 (tiga puluh) tahun. Dengan demikian, telah jelas bahwa usia pelaku kejahatan terorisme yang berinisial $\mathrm{M}$ termasuk ke kategori pemuda karena usianya 29 tahun, dimana usia tersebut berada diantara 16 (enam belas) tahun dan 30 (tiga puluh) tahun.

Dengan ini terbukti bahwa pelaku kejahatan terorisme tidak hanya dilakukan oleh orang yang yang dikategorikan telah melewati usia dewasa, melainkan dalam usia dewasa juga ada yang menjadi pelaku kejahatan terorisme. Oleh karena itu, sudah seharusnya kepada aparat penegak hukum beserta masyarakat Provinsi Jambi harus memperhatikan pemuda-pemudanya agar tidak terjerumus ke dalam kejahatan terorisme karena selain merugikan diri pemuda itu sendiri, kejahatan terorisme juga merasakan masyarakat di sekitarnya.

\section{METODE}

Untuk mendapatkan data dan mencari kebenaran di dalam suatu penelitian maka harus menggunakan metode penelitian. Metode yang digunakan dalam penelitian terkait dengan perlindungan hukum terhadap pemuda dari kejahatan terorisme di wilayah hukum Provinsi Jambi antara lain:

\section{Metode pendekatan}

Dalam melakukan penelitian hukum normatif diperlukan suatu pendekatan guna untuk mengetahui hubungan antara peraturan perundang-undangan yang berlaku dengan terjadinya permasalahan tersebut seperti terjadinya kejahatan terorisme. Untuk itu, terkait permasalahan kejahatan terorisme pendekatan dalam penelitian hukum normatif ini yaitu pendekatan kasus. Pendekatan kasus dilakukan dengan cara: ${ }^{9}$

1. Melakukan kajian terhadap kasus-kasus yang berkaitan dengan isu yang dihadapi yang telah menjadi putusan pengadilan yang telah mempunyai kekuatan hukum tetap.

2. Kasus ini dapat berupa kasus yang terjadi di Indonesia maupun di luar negara lain.

6 Teguh Prasetyo, Hukum Pidana, (Jakarta : Rajawali Press, 2010), hal 7.

7 Satijipto Raharjo, Ilmu Hukum, (Bandung : PT. Citra Aditya Bakti, 2000), hal 53.

${ }^{8} \mathrm{https} / / /$ nasional.tempo.co/read/880311/densus-88-tangkap-terduga-teroris-di-jambi-rt-akui-kecolongan, diunggah pada tanggal 28 Januari 2020.

${ }^{9}$ H. Salim Hs Dan Erlies Septiana Nurbani, Penerapan Teori Hukum Pada Penelitian Tesis Dan Disertasi, (Jakarta : PT. Raja Grafindo Persada, 2013), hal 18. 
3. Objek kajian pokok di dalam pendekatan kasus adalah ratio decidendi atau reasoning, yaitu pertimbangan pengadilan untuk sampai kepada suatu keputusan.

Dalam penelitian hukum normatif ini digunakan pendekatan kasus dengan cara-cara melakukan kajian terhadap kasus-kasus terkait dengan kejahatan terorisme yang ada di Provinsi Jambi dengan tujuan untuk mengetahui terkait dengan perlindungan hukum yang telah diatur dalam perundang-undangan tentang kejahatan terorisme.

Selanjutnya apabila dilihat dari pokok penelitian ini maka tipe dalam penelitian ini menggunakan penelitian hukum normatif. Soerjono Soekanto dan Sri Mamuji menyajikan pengertian penelitian hukum normatif adalah penelitian hukum yang dilakukan dengan cara meneliti bahan pustaka atau data sekunder. ${ }^{10} \mathrm{Jadi}$, hal yang diperhatikan dalam penelitian hukum normatif ini adalah mengamati setiap isi ketentuan-ketentuan yang terdapat dalam UndangUndang Nomor 5 Tahun 2018 Tentang Perubahan Atas Undang-Undang Nomor 15 Tahun 2003 Tentang Penetapan Peraturan Pemerintah Pengganti Undang-Undang Nomor 1 Tahun 2002 Tentang Pemberantasan Tindak Pidana Terorisme Menjadi Undang-Undang kemudian menelaah sejauhmana isi Undang-Undang Nomor 5 Tahun 2018 Tentang Perubahan Atas Undang-Undang Nomor 15 Tahun 2003 Tentang Penetapan Peraturan Pemerintah Pengganti Undang-Undang Nomor 1 Tahun 2002 Tentang Pemberantasan Tindak Pidana Terorisme Menjadi Undang-Undang tersebut telah melindungi kepentingan (hak-hak) masyarakat termasuk pemuda di Provinsi Jambi dari kejahatan terorisme.

\section{Rancangan kegiatan}

Di dalam penelitian perlindungan hukum terhadap pemuda dari kejahatan terorisme di wilayah hukum Provinsi Jambi ini yang dilakukan secara normatif maka rancangan kegiatan juga dibutuhkan dalam penelitian ini guna untuk memberikan hasil dari penelitian yang telah dilakukan oleh peneliti sesuai dengan yang diharapkan. Dalam penelitian ini dilaksanakan dalam jangka waktu 6 (enam) bulan. Sebenarnya rancangan kegiatan yang dibuat oleh peneliti bertujuan untuk mempermudah peneliti dalam melakukan penelitian terkait dengan permasalahan perlindungan hukum terhadap pemuda dari kejahatan terorisme di wilayah hukum Provinsi Jambi. Untuk itu, apabila dilihat dalam penelitian tentang perlindungan hukum terhadap pemuda dari kejahatan terorisme di wilayah hukum Provinsi Jambi dimana pendekatan dalam penelitian ini yaitu pendekatan kasus maka rancangan kegiatan Dilakukan dengan cara melihat langsung kasus yang telah terjadi dan kemudian dikaitkan dengan perlindungan hukum yang terdapat di dalam Undang-Undang Nomor 5 Tahun 2018 Tentang Perubahan Atas Undang-Undang Nomor 15 Tahun 2003 Tentang Penetapan Peraturan Pemerintah Pengganti Undang-Undang Nomor 1 Tahun 2002 Tentang Pemberantasan Tindak Pidana Terorisme Menjadi Undang-Undang.

\section{Ruang lingkup atau objek}

Ruang lingkup dalam penelitian tentang perlindungan hukum terhadap pemuda dari kejahatan terorisme di wilayah hukum Provinsi Jambi ini guna untuk memberi batasan di dalam mengkaji permasalahan tentang perlindungan hukum terhadap pemuda dari kejahatan terorisme di wilayah hukum Provinsi Jambi sehingga penelitian ini hukum kepada permasalahan tersebut. Dengan demikian, ruang lingkup dalam penelitian ini adalah mengkaji terkait dengan perlindungan hukum dalam Undang-Undang Nomor 5 Tahun 2018 Tentang Perubahan Atas UndangUndang Nomor 15 Tahun 2003 Tentang Penetapan Peraturan Pemerintah Pengganti Undang-Undang Nomor 1 Tahun 2002 Tentang Pemberantasan Tindak Pidana Terorisme Menjadi Undang-Undang terhadap pemuda dari kejahatan terorisme di wilayah hukum Provinsi Jambi yang diberikan oleh pemerintah Provinsi Jambi dan aparat penegak hukum.

Objek kajian dalam penelitian sebenarnya memfokuskan pada permasalahan yang sedang diteliti untuk mendapatkan menyelesaikan permasalahan tersebut. Untuk itu, apabila dalam penelitian tentang perlindungan hukum terhadap pemuda dari kejahatan terorisme di wilayah hukum Provinsi Jambi ini objek kajiannya adalah pemuda Provinsi Jambi maka penelitian ini memfokuskan terhadap pemuda Provinsi Jambi agar terhindar dari adanya pengrekrutan kejahatan terorisme.

Selain itu juga, penelitian ini dilakukan spesifikasi penelitian untuk memberikan kemudahan dalam memahami pokok permasalahan yang sedang diteliti. Oleh karena itu, spesifikasi penelitian dalam penelitian perlindungan hukum terhadap pemuda dari kejahatan terorisme di wilayah hukum Provinsi Jambi ini bersifat deskriptif kualitatif. Penelitian deskriptif adalah penelitian yang bertujuan untuk melukiskan tentang hal di daerah dan saat tertentu. Biasanya peneliti telah mendapat gambaran berupa data awal tentang permasalahannya. ${ }^{11}$

${ }^{10}$ Soerjono Soekanto dan Sri Mamuji, Penelitian Hukum Normatif Suatu Tinjauan Singkat, (Jakarta : Raja Grafindo Persada, 2010), hal 13-14.

${ }^{11}$ H. Salim Hs Dan Erlies Septiana Nurbani, Op.Cit, hal 9. 
Apabila dilihat dari pokok permasalahan yang diteliti maka penelitian ini meneliti permasalahan yang sedang terjadi di Provinsi Jambi terkait dengan adanya kejahatan terorisme dan melihat sejauhmana perlindungan hukum tersebut telah diberikan terhadap pemuda yang ada di Provinsi Jambi dari kejahatan terorisme.

\section{Bahan dan alat utama}

Dalam melakukan suatu penelitian tentunya harus menggunakan sumber data untuk mencari kebenaran di dalam penelitian itu sendiri. Oleh karena itu, bahan penelitian hukum normatif bersumber dari data sekunder, dimana data sekunder ini didapatkan dari bahan kepustakaan yang memiliki hubungan dengan objek di dalam penelitian yang kita teliti. Untuk itu, terkait dengan sumber data sekunder maka penulis mengambil dari bahan kepustakaan seperti buku-buku dan website internet yang terpercaya dan ada hubungannya dengan pokok penelitian yaitu terkait dengan kejahatan terorisme.

Setelah mempelajari buku-buku dan website internet, kemudian peneliti melihat sejauhmana isi UndangUndang Nomor 5 Tahun 2018 Tentang Perubahan Atas Undang-Undang Nomor 15 Tahun 2003 Tentang Penetapan Peraturan Pemerintah Pengganti Undang-Undang Nomor 1 Tahun 2002 Tentang Pemberantasan Tindak Pidana Terorisme Menjadi Undang-Undang telah melindungi pemuda yang ada di Provinsi Jambi dari kejahatan terorisme. Sedangkan alat utama di dalam penelitian ini adalah mernggunakan alat elektronik seperti leptop atau computer guna untuk membuat hasil penelitian ini.

\section{Teknik Pengumpulan Data}

Di dalam mengumpulkan data primer tentunya digunakan teknik pengumpulan data. Adapun teknik pengumpulan data dalam penelitian ini adalah studi dokumen. Studi dokumen merupakan studi yang mengkaji tentang berbagai dokumen-dokumen, baik yang berkaitan dengan peraturan perundang-undangan maupun dokumen-dokumen yang sudah ada. ${ }^{12} \mathrm{Jadi}$, di dalam penelitian hukum normatif ini peneliti melakukan sudi dokumennya berupa mengkaji isi Undang-Undang Nomor 5 Tahun 2018 Tentang Perubahan Atas Undang-Undang Nomor 15 Tahun 2003 Tentang Penetapan Peraturan Pemerintah Pengganti Undang-Undang Nomor 1 Tahun 2002 Tentang Pemberantasan Tindak Pidana Terorisme Menjadi Undang-Undang dan buku-buku serta website internet yang ada hubungannya dengan pemuda dan kejahatan terorisme.

\section{Teknik Analisis}

Mengingat di dalam penelitian perlindungan hukum terhadap pemuda dari kejahatan terorisme di wilayah hukum Provinsi Jambi merupakan penelitian hukum normatif maka analisis datanya dilakukan secara kualitatif. Secara kualitatif yakni menguraikan data secara berkualitas dan komprehensif dalam bentuk kalimat yang teratur, logis, tidak tumpang tindih dan efektif sehingga memudahkan pemahaman dan interpretasi data. ${ }^{13}$

Dengan demikian, dalam penelitian normatif ini memberikan penjelasan terkait dengan hal yang diteliti sesuai data yang yang ada dimana data tersebut memiliki mutu yang berkualitas dan hasil penelitian ini dibuat dalam bentuk kalimat-kalimat yang teratur dan sistematik, dimana kalimat-kalimat tersebut akan dituangkan di dalam pembahasan penelitian ini.

\section{HASIL DAN PEMBAHASAN}

\section{Perlindungan Hukum Terhadap Pemuda Dari Kejahatan Terorisme Di Wilayah Hukum Provinsi Jambi}

Dalam perkembangannya terorisme ini dilakukan tidak satu wilayah saja, melainkan juga terus semua ini dilakukan di semua wilayah karena kelompok teroris ini mempunyai simpatisan di berbagai wilayah, bahkan tidak menutup kemungkinan penyebaran teror ini dapat dilakukan sampai dengan melewati batas-batas negara atau wilayah tersebut. Hal ini dikatakan demikian karena perkembangan terorisme itu sendiri tidak dapat lepas dari pergerakan maupun pengrekrutan anggotanya, di mana hanya merekrut orang-orang yang mau ikut dalam aksi teror itu saja, akan tetapi untuk sekarang ini pengrekrutan tersebut mulai dilakukan terhadap pemuda di seluruh wilayah.

Pengrekrutan kejahatan terorisme untuk sekarang ini berbeda dengan pengrekrutan seperti dulu. Hal ini dikatakan demikian karena menurut Narasumber dahulu pengrekrutan anggota terorisme ini lebih menekankan kepada ada orang yang lebih matang dan berpengalaman dibidang teror, akan tetapi untuk sekarang ini dalam perekrutan kejahatan terorisme dibutuhkan pengrekrutan terhadap pemuda. Hal ini terjadi telah terbukti dari adanya pelaku tindak pidana terorisme yang berinisial M, 29 tahun, satu dari dua orang terduga teroris yang diamankan Densus 88 anti teror, selama mengontrak bersama istrinya di salah satu rumah di kawasan Rukun Tetangga (RT) 35, Kelurahan Kenali Besar, Kecamatan Alam Barajo, Kota Jambi, diketahui tidak pernah melapor kepada ketua RT setempat. ${ }^{14}$

\footnotetext{
${ }^{12} \mathrm{Ibid}$, hal 19.

${ }^{13}$ Ishaq, Metode Penelitian Hukum, (Bandung : Alfabeta, 2017), hal 73.

${ }^{14}$ https://nasional.tempo.co/read/880311/densus-88-tangkap-terduga-teroris-di-jambi-rt-akui-kecolongan, diunggah pada tanggal 28 Januari 2020.
} 
Untuk itu, pengrekrutan kejahatan terorisme terhadap pemuda ini dilakukan karena pemuda dirasakan masih labil dan mempunyai idealisme yang tinggi serta mudah dipengaruhi cara berpikirnya sehingga para pemuda tersebut akan tunduk pada pimpinan terorisme. Selain itu juga, bagi pemuda yang tidak mau mengikuti pengrekrutan tersebut akan diteror sehingga membuat rasa pemuda itu sendiri dan tidak menutup kemungkinan mereka mau tidak mau agar tidak diteror terus menerus maka dengan terpaksa para pemuda itu mengikuti pengrekrutan terorisme itu sendiri. Hal yang demikian ini sangat dikhawatirkan karena mengingat pemuda merupakan cikal bakal penerus bangsa Indonesia sebab pemuda inilah yang menentukan Indonesia maju atau tidaknya.

Sebenarnya kejahatan terorisme saat ini tidak asing lagi didengar karena berita terkait dengan kejahatan terorisme telah beredar luas baik di media cetak seperti koran dan majalah maupun media elektronik seperti berita di televisi dan internet sehingga dibutuhkan kewaspadaan terhadap kejahatan terorisme ini sebab kejahatan ini tidak hanya mengancam pihak pemerintah dan masyarakat umum saja, melainkan juga dapat mengancam pemuda sebagai generasi penerus bangsa. Oleh karena itu, sudah seharusnya dibutuhkan perlindungan hukum terhadap pemuda dari kejahatan terorisme di Provinsi Jambi. Diadakan perlindungan hukum terhadap Pemuda tersebut dikarenakan Pemuda inilah yang sering menjadi korban dari kejahatan terorisme dan pemuda ini juga harus dilindungi haknya sebagai warga negara Indonesia dari adanya kejahatan terorisme itu sendiri.

Pemuda di Provinsi Jambi sudah seharusnya ada perlindungan hukum sehingga pemuda-pemuda tersebut yang ada di Provinsi Jambi dapat terlindungi dari ancaman kejahatan terorisme. Dengan adanya perlindungan hukum ini maka para pemuda di Provinsi Jambi dapat beraktivitas seperti biasanya dengan tenang. Selain itu juga, diadakan perlindungan hukum terhadap pemuda dikarenakan pemuda dalam kejahatan terorisme ini adalah pihak yang masih mudah terpengaruh sehingga mudah untuk di bujuk rayu untuk terlibat di dalam melakukan terorisme.

Dengan mudah terpengaruhnya pemuda untuk bergabungnya menjadi anggota terorisme itu maka para pemuda dapat menjadi korban dari kejahatan terorisme itu sendiri. Oleh karena itu, untuk menghindari para pemuda yang ada di Provinsi Jambi akan bahaya dari kejahatan terorisme tersebut maka para pemuda di Provinsi Jambi harus dilindungi oleh hukum dari berbagai ancaman yang mengancam dirinya terutama ancaman dari kejahatan terorisme itu sendiri.

Untuk menghindari adanya korban kejahatan terorisme yang berasal dari Pemuda maka Badan Nasional Penanggulangan Terorisme atau biasa yang singkat dengan BNPT dan dibentuk pada 16 Juli 2010. Adapaun tugas Badan Nasional Penanggulangan Terorisme (BNPT) dalam Pasal 2 Peraturan Presiden Nomor 46 Tahun 2010 Tentang Badan Penanggulangan Terorisme yaitu

1. Menyusun kebijakan, strategi, dan program nasional di bidang penanggulangan terorisme.

2. Mengkoordinasikan instansi pemerintah terkait dalam pelaksanaan dan melaksanakan kebijakan di bidang penanggulangan terorisme.

3. Melaksanakan kebijakan di bidang penanggulangan terorisme dengan membentuk Satuan Tugas-Satuan Tugas yang terdiri dari unsur-unsur instansi pemerintah terkait sesuai dengan tugas, fungsi dan kewenangan masingmasing.

Kemudian dalam menanggulangi terjadinya kejahatan terorisme maka Badan Nasional Penanggulangan Terorisme (BNPT) membentuk kepengurusan Forum Komunikasi Penanggulangan Terorisme (FKPT) di Provinsi Jambi. Dasar pembentukan lembaga ini adalah Keputusan Kepala Badan Nasional Penanggulangan Terorisme Nomor: KEP-02/K.BNPT/1/2012 tentang Pembentukan Forum Koordinasi Pencegahan Terorisme (FKPT) di Daerah. ${ }^{15}$ Dalam Pasal 1 ayat (3) Keputusan Kepala Badan Nasional Penanggulangan Terorisme Nomor: KEP-02/K.BNPT/1/2012 tentang Pembentukan Forum Koordinasi Pencegahan Terorisme (FKPT) menjelaskan bahwa Badan Nasional Penanggulangan Terorisme selanjutnya disebut BNPT adalah Lembaga Pemerintah Non Kementerian, berada di bawah dan bertanggung jawab langsung kepada Presiden yang dibentuk dalam rangka menjalankan tugas dan fungsi penanggulangan terorisme.

Tugas dari Forum Koordinasi Pencegahan Terorisme (FKPT) yang diatur dalam Pasal 8 Keputusan Kepala Badan Nasional Penanggulangan Terorisme Nomor: KEP-02/K.BNPT/1/2012 tentang Pembentukan Forum Koordinasi Pencegahan Terorisme (FKPT) yang berbunyi bahwa dalam melaksanakan tugas sebagaimana dimaksud dalam Pasal 7, FKPT dapat melakukan:

1. Penelitian tentang potensi radikal terorisme.

2. Pembuatan peta sistem siaga dini bahaya terorisme.

3. Pengembangan potensi positif dan kreatif untuk pemuda dan perempuan.

4. Edukasi anti radikalisme dan terorisme kepada semua elemen masyarakat di daerah dan pengembangan kreativitasnya dari berbagai perspektif.

5. Literasi media kontra-ideologi radikal melalui media massa, media sosial dan media lainnya.

${ }^{15}$ Mohammad Hasan Ansori, dkk, Memberantas Terorisme Di Indonesia : Praktek, Kebijakan Dan Tantangan, (Jakarta : The Habibie Center, 2019), hal 55. 
6. Advokasi kepada masyarakat yang menjadi korban aksi terorisme.

7. Pembinaan terhadap napi teroris, mantan napi teroris, keluarga, dan jaringannya.

8. Pembinaan terhadap orang/kelompok potensi radikal terorisme.

Dengan dibentuknya Forum Komunikasi Penanggulangan Terorisme (FKPT) ini bertujuan untuk melindungi masyarakat Jambi terutama para pemuda di Provinsi Jambi akan adanya kejahatan terorisme yang sekarang ini sering terjadi. Selain itu juga, apabila terdapat informasi baik dari pemuda maupun masyarakat Provinsi Jambi terkait dengan adanya kejahatan terorisme di sekitar tempat tinggalnya maka Pemuda maupun masyarakat Provinsi Jambi tersebut dapat melakukan pengaduan kepada Forum Komunikasi Penanggulangan Terorisme (FKPT).

Sebenarnya Forum Komunikasi Penanggulangan Terorisme (FKPT) ini terbentuk sesuai dengan tugas dan perannya yaitu melakukan penelitian tentang potensi adanya terorisme dan mengembangkan potensi serta kreativitas yang ada terdapat diri pemuda yang ada di Provinsi Jambi dalam mencegah terjadinya terorisme di Provinsi Jambi. Selain itu, juga memberikan edukasi kepada para pemuda yang ada di provinsi Jambi agar dapat menghindari dirinya untuk tidak terlibat menjadi anggota terorisme.

Kondisi seperti ini dilakukan karena mengingat paham terkait dengan terorisme banyak ditemukan di kampuskampus, termasuk juga kampus yang ada di Provinsi Jambi. Untuk itu, untuk menghindari para pemuda dan mahasiswa agar tidak terlibat di dalam kejahatan terorisme maka Forum Komunikasi Penanggulangan Terorisme (FKPT) juga melakukan sosialisasi yang bersifat keagamaan melalui lembaga dakwah kampus agar mahasiswa dan para pemuda yang ada di provinsi Jambi terhindar dari konten provokatif sehingga menjerumuskan mereka menjadi pelaku kejahatan terorisme.

Dengan adanya Forum Komunikasi Penanggulangan Terorisme (FKPT) tersebut maka sudah ada perlindungan terhadap pemuda dari kejahatan terorisme. Walaupun telah ada perlindungan terhadap Pemuda dari kejahatan terorisme agar pemuda tersebut tidak menjadi korban kejahatan terorisme, harus ada juga perlindungan hukum untuk menjerat pelaku kejahatan terorisme agar dapat dihukum karena mengingat kejahatan terorisme sangat membahayakan bangsa dan negara serta meresahkan masyarakat terutama pemuda di Provinsi Jambi. Hal ini dikatakan demikian karena perlindungan hukum selain memberikan pengayoman kepada hak asasi manusia yang telah dirugikan yaitu korban dari adanya kejahatan terorisme, perlindungan hukum juga memberikan hukuman kepada setiap orang yang melakukan kejahatan termasuk juga kejahatan terorisme.

Demikian juga senada dengan pendapat Satjipto Raharjo bahwa perlindungan hukum adalah berbagai upaya hukum yang harus diberikan oleh aparat penegak hukum untuk memberikan rasa aman, baik secara pikiran maupun fisik dari gangguan dan berbagai ancaman dari pihak manapun. ${ }^{16}$ Ini berarti dengan adanya upaya hukum dari aparat penegak hukum maka terhadap siapa saja pelaku kejahatan termasuk juga kejahatan terorisme harus dijatuhkan dengan hukuman atau sanksi pidana yang terdapat dalam Undang-Undang Nomor 5 Tahun 2018 Tentang Perubahan Atas Undang-Undang Nomor 15 Tahun 2003 Tentang Penetapan Peraturan Pemerintah Pengganti Undang-Undang Nomor 1 Tahun 2002 Tentang Pemberantasan Tindak Pidana Terorisme Menjadi Undang-Undang.

Mengingat akan bahayanya kejahatan terorisme baik terhadap masyarakat maupun pemuda, sebenarnya di dalam Undang-Undang Nomor 5 Tahun 2018 Tentang Perubahan Atas Undang-Undang Nomor 15 Tahun 2003 Tentang Penetapan Peraturan Pemerintah Pengganti Undang-Undang Nomor 1 Tahun 2002 Tentang Pemberantasan Tindak Pidana Terorisme Menjadi Undang-Undang telah diatur terkait dengan perlindungan terhadap korban kejahatan terorisme. Adapun aturan tentang perlindungan terhadap korban dari kejahatan terorisme terdapat dalam BAB VI pada Pasal 35A yang berisikan sebagai berikut:

(1) Korban merupakan tanggung jawab negara.

(2) Korban sebagaimana dimaksud pada ayat (1) meliputi :

a. Korban langsung; atau

b. Korban tidak langsung.

(3) Korban sebagaimana dimaksud pada ayat (1) ditetapkan oleh penyidik berdasarkan hasil olah tempat kejadian Tindak Pidana Terorisme.

(4) Bentuk tanggung jawab negara sebagaimana dimaksud pada ayat (1) berupa:
a. Bantuan medis.
b. Rehabilitasi psikososial dan psikologis.
c. Santunan bagi keluarga dalam hal Korban meninggal dunia dan
d. Kompensasi.

Apabila dilihat dari isi pasal 35A Undang-Undang Nomor 5 Tahun 2018 Tentang Perubahan Atas UndangUndang Nomor 15 Tahun 2003 Tentang Penetapan Peraturan Pemerintah Pengganti Undang-Undang Nomor 1 Tahun

${ }^{16}$ Satjipto Rahardjo, Ilmu hukum, (Bandung : Citra Aditya Bakti, 2000), Hal 74. 
2002 Tentang Pemberantasan Tindak Pidana Terorisme Menjadi Undang-Undang di atas maka telah jelas bahwa perlindungan terhadap korban kejahatan terorisme dapat berupa bantuan medis, rehabilitasi psikososial dan psikologis serta santunan bagi keluarga dalam hal korban meninggal dunia dan kompensasi.

Perlindungan di dalam pasal 35A Undang-Undang Nomor 5 Tahun 2018 Tentang Perubahan Atas UndangUndang Nomor 15 Tahun 2003 Tentang Penetapan Peraturan Pemerintah Pengganti Undang-Undang Nomor 1 Tahun 2002 Tentang Pemberantasan Tindak Pidana Terorisme Menjadi Undang-Undang ini merupakan perlindungan hukum karena melindungi subjek hukum baik orang maupun masyarakat Provinsi Jambi melalui Undang-Undang Nomor 5 Tahun 2018 Tentang Perubahan Atas Undang-Undang Nomor 15 Tahun 2003 Tentang Penetapan Peraturan Pemerintah Pengganti Undang-Undang Nomor 1 Tahun 2002 Tentang Pemberantasan Tindak Pidana Terorisme Menjadi Undang-Undang. Hal ini juga senada dengan pendapat Satijipto Raharjo yang menyatakan bahwa perlindungan hukum adalah memberikan pengayoman terhadap hak asasi manusia (HAM) yang dirugikan orang lain dan perlindungan itu di berikan kepada masyarakat agar dapat menikmati semua hak-hak yang diberikan oleh hukum. ${ }^{17}$

Dengan adanya Undang-Undang Nomor 5 Tahun 2018 Tentang Perubahan Atas Undang-Undang Nomor 15 Tahun 2003 Tentang Penetapan Peraturan Pemerintah Pengganti Undang-Undang Nomor 1 Tahun 2002 Tentang Pemberantasan Tindak Pidana Terorisme Menjadi Undang-Undang ini maka telah melindungi hak-hak subjek hukum agar terlindungi dari adanya kejahatan terorisme dan sekaligus mencegah sebelum terjadinya kejahatan terorisme. Hal ini juga sependapat dengan pendapat Phillipus M. Hadjon bahwa perlindungan hukum yang preventif bertujuan untuk mencegah terjadinya sengketa, yang mengarahkan tindakan pemerintah berikap hati-hati dalam pengambilan keputusan berdasarkan diskresi. ${ }^{18}$ Ini berarti bahwa Undang-Undang Nomor 5 Tahun 2018 Tentang Perubahan Atas Undang-Undang Nomor 15 Tahun 2003 Tentang Penetapan Peraturan Pemerintah Pengganti Undang-Undang Nomor 1 Tahun 2002 Tentang Pemberantasan Tindak Pidana Terorisme Menjadi Undang-Undang yang dikeluarkan oleh pemerintah bersifat preventif (sebelum terjadi).

Selain itu juga, perlindungan hukum yang bersifat preventif dapat dilakukan oleh aparat penegak hukum dengan cara memberikan sosialisasi terhadap para pemuda yang ada di Provinsi Jambi untuk dapat menghindari dirinya dari pengrekrutan kelompok terorisme. Dengan dilakukannya sosialisasi oleh aparat hukum ini maka para pemuda di Provinsi Jambi dapat lebih waspada akan adanya pengrekrutan anggota terorisme dan mereka juga dapat terlindungi dari adanya kejahatan terorisme yang belakangan ini marak terjadi.

Tidak hanya aparat penegak hukum saja yang dapat melakukan sosialisasi terhadap para pemuda Provinsi Jambi khususnya terkait dengan kejahatan terorisme, Forum Komunikasi Penanggulangan Terorisme (FKPT) Provinsi Jambi juga dapat melakukan penyuluhan atau sosialisasi terhadap masyarakat provinsi Jambi khususnya para pemuda untuk tidak mudah dibujuk rayu oleh anggota terorisme. Dengan adanya sosialisasi atau penyuluhan ini maka dapat mencegah agar para pemuda yang ada di Provinsi Jambi tidak menjadi anggota terorisme dan terhindar dari adanya kejahatan terorisme itu sendiri.

Perlindungan hukum melalui jalur preventif ini sangat diperlukan karena mengingat kejahatan terorisme yang semakin marak terjadi di dalam masyarakat sehingga diperlukan antisipasi terlebih dahulu agar kejahatan terorisme itu tidak terjadi di dalam masyarakat khususnya terhadap para pemuda di Provinsi Jambi. Sebenarnya perlindungan hukum dengan menggunakan jalur preventif ini bertujuan untuk meminimalisir tingkat kejahatan terorisme itu sendiri sehingga dengan dapat diminimalisirnya tingkat kejahatan terorisme maka tidak akan banyak korban yang berjatuhan dari kejahatan terorisme itu sendiri terutama terhadap pemuda yang ada di Provinsi Jambi.

Sementara itu Abintoro Prakoso mengatakan yang pada intinya yaitu sebenarnya upaya pencegahan kejahatan harus berfokus kepada adanya akar kejahatan itu sendiri. ${ }^{19}$ Dengan terfokus kepada akar kejahatan dalam hal ini terfokus pada kejahatan terorisme maka upaya penanggulangan kejahatan terorisme dapat dilakukan oleh pemerintah dan aparat penegak hukum. Ini berarti bahwa perlindungan hukum melalui jalur preventif lebih efektif di dalam upaya pencegahan kejahatan terorisme. Dikatakan lebih efektif karena perlindungan hukum dengan cara preventif ini lebih memfokuskan pada akar kejahatan terorisme sehingga apabila telah memfokuskan pada akar kejahatan terorisme tersebut maka dimungkinkan tidak akan terjadi kejahatan terorisme pada pemuda.

Selain itu, pencegahan kejahatan (upaya non penal) memfokuskan diri pada campur tangan sosial, ekonomi dan berbagai area kebijakan publik dengan maksud mencegah terjadinya kejahatan. ${ }^{20}$ Ini berarti bahwa di dalam mencegah terjadinya kejahatan terorisme yang marak terjadi di dalam masyarakat maka dengan adanya campur tangan sosial seperti peran dari masyarakat dalam hal melaporkan adanya kejahatan terorisme di sekitar tempat tinggalnya sehingga dengan adanya laporan dari masyarakat tersebut, para pelaku kejahatan terorisme tidak akan berani melakukan teror

\footnotetext{
${ }^{17}$ Ibid, Hal 54.

${ }^{18}$ Phillipus M. Hadjon, Perlindungan Hukum Bagi Rakyat Indonesia, (Surabaya : PT. Bina Ilmu, 1987), Hal 2.

${ }^{19}$ Abintoro Prakoso, Kriminologi Dan Hukum Pidana, (Yogyakarta : Laksbang Grafika, 2013), Hal 160.

${ }^{20}$ Ibid.
} 
terhadap masyarakat maupun pemuda Provinsi Jambi. Untuk itu, peran masyarakat dan para pemuda sangat dibutuhkan dalam mengatasi kejahatan terorisme yang seringkali terjadi khususnya di Provinsi Jambi.

Selain menggunakan jalur preventif dalam memberikan perlindungan hukum terhadap pemuda Provinsi Jambi dari kejahatan terorisme, dapat juga digunakan jalur represif di dalam memberantas kejahatan terorisme itu sendiri. Secara kasar dapat dibedakan bahwa upaya penanggulangan kejahatan lewat jalur penal lebih menitikberatkan pada sifat represive (penindasan/pemberantasan/penumpasan) sesudah kejahatan terjadi. ${ }^{21}$ Untuk itu, apabila telah terjadi kejahatan terorisme pada pemuda maka aparat penegak hukum beserta Forum Komunikasi Penanggulangan Terorisme (FKPT) cepat menggunakan cara represif untuk menjerat pelaku kejahatan terorisme tersebut. Sebenarnya digunakan jalur represif ini karena kejahatan terorisme tersebut telah terjadi di dan telah ada korban dari kejahatan terorisme itu sendiri, dimana yang menjadi korban dari kejahatan terorisme ini yaitu pemuda yang ada di Provinsi Jambi.

Mengingat kondisi kejahatan terorisme yang sangat membahayakan terhadap pemuda yang menjadi generasi penerus bangsa maka sudah seharusnya dibutuhkan perlindungan hukum yang tegas dengan menggunakan jalur represif. Jalur Represif dalam hal ini maksudnya melakukan perlindungan terhadap korban dari ancaman kejahatan terorisme melalui pengadilan. Jika dilakukan melalui pengadilan ini berarti penanggulangan kejahatan terorisme dilaksanakan secara paksa terhadap pelaku kejahatan teroris berupa penjatuhan sanksi pidana yang terdapat di dalam Undang-Undang Nomor 5 Tahun 2018 Tentang Perubahan Atas Undang-Undang Nomor 15 Tahun 2003 Tentang Penetapan Peraturan Pemerintah Pengganti Undang-Undang Nomor 1 Tahun 2002 Tentang Pemberantasan Tindak Pidana Terorisme Menjadi Undang-Undang.

Dengan dijatuhkannya sanksi pidana yang terdapat di dalam Undang-Undang Nomor 5 Tahun 2018 Tentang Perubahan Atas Undang-Undang Nomor 15 Tahun 2003 Tentang Penetapan Peraturan Pemerintah Pengganti UndangUndang Nomor 1 Tahun 2002 Tentang Pemberantasan Tindak Pidana Terorisme Menjadi Undang-Undang sebenarnya diharapkan agar pelaku terorisme yang belum melakukan aksinya untuk dapat mengurungkan niatnya untuk melakukan kejahatan terorisme. Hal ini dikatakan demikian karena dengan penjatuhan sanksi pidana tersebut telah mencegah terjadinya kejahatan terorisme. Menurut Muladi dan Barda Nawawi Arief bahwa pidana harus ditetapkan berdasar tujuannya sebagai alat untuk pencegahan kejahatan. ${ }^{22}$ Dengan demikian, penjatuhan pidana terhadap pelaku kejahatan terorisme merupakan upaya pencegahan agar kejahatan terorisme tidak terjadi.

Tidak hanya itu saja, dengan dijatuhkannya sanksi pidana terhadap pelaku kejahatan terorisme maka akan memberi efek jera untuk tidak melakukan kejahatan terorisme di kemudian hari dan tentunya penjatuhan sanksi pidana yang harus dijalankan oleh pelaku kejahatan terorisme tidak ringan sebab mengingat beratnya sanksi pidana yang tercantum di dalam Undang-Undang Nomor 5 Tahun 2018 Tentang Perubahan Atas Undang-Undang Nomor 15 Tahun 2003 Tentang Penetapan Peraturan Pemerintah Pengganti Undang-Undang Nomor 1 Tahun 2002 Tentang Pemberantasan Tindak Pidana Terorisme Menjadi Undang-Undang berupa pidana penjara, pidana seumur hidup bahkan pidana mati terhadap pelaku kejahatan terorisme.

\section{SIMPULAN}

Perlindungan hukum terhadap pemuda dari kejahatan terorisme di wilayah hukum Provinsi Jambi yaitu dalam hal preventif adalah pemerintah telah mengeluarkan Undang-Undang Nomor 5 Tahun 2018 Tentang Perubahan Atas Undang-Undang Nomor 15 Tahun 2003 Tentang Penetapan Peraturan Pemerintah Pengganti Undang-Undang Nomor 1 Tahun 2002 Tentang Pemberantasan Tindak Pidana Terorisme Menjadi Undang-Undang untuk memberikan perlindungan kapada pemuda untuk tidak menjadi korban kejahatan terorisme dan aparat penegak hukum beserta Forum Komunikasi Penanggulangan Terorisme (FKPT) melakukan sosialisasi dan penyuluhan terkait dengan bahayanya kejahatan terorisme, sedangkan dalam hal represif yaitu pemerintah melalui Undang-Undang Nomor 5 Tahun 2018 Tentang Perubahan Atas Undang-Undang Nomor 15 Tahun 2003 Tentang Penetapan Peraturan Pemerintah Pengganti Undang-Undang Nomor 1 Tahun 2002 Tentang Pemberantasan Tindak Pidana Terorisme Menjadi Undang-Undang beserta aparat penegak hukum dalam menjalankan aturan ini menjerat pelaku kejahatan terorisme dengan menjatuhkan sanksi pidana.

\section{DAFTAR PUSTAKA}

\section{Buku}

Ansori, Mohammad Hasan, dkk. Memberantas Terorisme Di Indonesia: Praktek, Kebijakan Dan Tantangan, Jakarta:

The Habibie Center, 2019

El, Muhtas Majda. Dimensi Dimensi HAM, Jakarta : PT. Raja Grafindo Persada, 2008

Hadjon, Phillipus M. Perlindungan Hukum Bagi Rakyat Indonesia, Surabaya : PT. Bina Ilmu, 1987

\footnotetext{
${ }^{21}$ Ibid.

${ }^{22}$ Muladi dan Barda Nawawi Arief, Bunga Rampai Hukum Pidana, (Bandung: Alumni, 1998), Hal 20-21.
} 
Hs, H. Salim Dan Erlies Septiana Nurbani. Penerapan Teori Hukum Pada Penelitian Tesis Dan Disertasi, Jakarta : PT. Raja Grafindo Persada, 2013

Ishaq, Metode Penelitian Hukum, Bandung : Alfabeta, 2017

Muladi dan Barda Nawawi Arief, Bunga Rampai Hukum Pidana, Bandung: Alumni, 1998

Prakoso, Abintoro. Kriminologi Dan Hukum Pidana, Yogyakarta : Laksbang Grafika, 2013

Prasetyo, Teguh. Hukum Pidana, Jakarta : Rajawali Press, 2010

Rahardjo, Satjipto. Ilmu hukum, Bandung : Citra Aditya Bakti, 2000

Soekanto, Soerjono dan Sri Mamuji. Penelitian Hukum Normatif Suatu Tinjauan Singkat, Jakarta : Raja Grafindo Persada, 2010

Sunardi, Abdul Wahid dan Muhammad Imam Sidik. Kejahatan Terorisme Perspektif Agama, HAM dan Hukum, Bandung : Retika Aditama, 2004

\section{Peraturan Perundang-Undangan}

Republik Indonesia, Undang-Undang Nomor 39 Tahun 1999 Tentang Hak Asasi Manusia

Republik Indonesia, Undang-Undang Nomor 5 Tahun 2018 Tentang Perubahan Atas Undang-Undang Nomor 15

Tahun 2003 Tentang Penetapan Peraturan Pemerintah Pengganti Undang-Undang Nomor 1 Tahun 2002

Tentang Pemberantasan Tindak Pidana Terorisme Menjadi Undang-Undang

Republik Indonesia, Undang-Undang Nomor 40 Tahun 2019 tentang Kepemudaan

\section{Website}

https://wartakota.tribunnews.com/2019/12/19/kronologi-anggota-densus-88-ditikam-terduga-teroris-di-jambi-sempatterjadi-pergumulan-2-lawan-1

https://nasional.tempo.co/read/880311/densus-88-tangkap-terduga-teroris-di-jambi-rt-akui-kecolongan 